This is the accepted manuscript of the following article:

Yan, Y., Rentsch, D., Battaglia, C., \& Remhof, A. (2017). Synthesis, stability and Li-ion mobility of nanoconfined Li2B12H12. Dalton Transactions, 46(37), 12434-12437. http://doi.org/10.1039/

\title{
C7DT02946B
}

\section{Synthesis, Stability and Li-ion Mobility of Nanoconfined $\mathrm{Li}_{2} \mathrm{~B}_{12} \mathrm{H}_{12}$}

Received 00th January 20xx,

\author{
Y. Yan, ${ }^{a, c *}$ D. Rentsch, ${ }^{b}$ C. Battaglia ${ }^{c}$ and A. Remhof ${ }^{c}$
}

Accepted 00th January 20xx

DOI: $10.1039 / x 0 \times x 00000 x$

www.rsc.org/

This communication presents the first synthesis of nanoconfined Lithium closo-borate, $\mathrm{Li}_{2} \mathrm{~B}_{12} \mathrm{H}_{12}$, using nanoporous $\mathrm{SiO}_{2}$ as scaffold. The yield of $\mathrm{Li}_{2} \mathrm{~B}_{12} \mathrm{H}_{12}$ is up to $94 \mathrm{~mol} \%$. The as-synthesized nanoconfined $\mathrm{Li}_{2} \mathrm{~B}_{12} \mathrm{H}_{12}$ exhibites a structual transition around 380 ${ }^{\circ} \mathrm{C}$ and conversion to $\mathrm{H}$-deficiency $\mathrm{Li}_{2} \mathrm{~B}_{12} \mathrm{H}_{12-\mathrm{x}}$ at $580^{\circ} \mathrm{C}$.

Complex hydrides, based on complex anions such as $\left[\mathrm{BH}_{4}\right]^{-},\left[\mathrm{NH}_{2}\right]$ and $\left[\mathrm{B}_{12} \mathrm{H}_{12}\right]^{2-}$, have been attracting great attention as energystorage materials. ${ }^{1-5}$ Lithium closo-borate, $\mathrm{Li}_{2} \mathrm{~B}_{12} \mathrm{H}_{12}$, has been extensively discussed as a reaction intermediate in the hydrogen sorption process of bulk $\mathrm{LiBH}_{4}{ }^{6-10}$ Due to its high thermal stability and low chemical reactivity, it has been considered as a boron sink hindering the rehydrogenation of $\mathrm{LiBH}_{4}$.

Recently, fast ion conduction has been discovered in closo-borate anion based complex hydrides. ${ }^{11-20}$ Their high thermal stability and low chemical reactivity are obviously big advantages regarding potential application as $\mathrm{Li}$ solid-state electrolytes. $\mathrm{Li}_{2} \mathrm{~B}_{12} \mathrm{H}_{12}$ crystallizes in two polymorphs, the low conducting $\alpha$-phase at room temperature and the highly conducting, disordered $\beta$-phase above $355{ }^{\circ} \mathrm{C}^{21}$ showing Li-ion conductivity of around $0.1 \mathrm{~S} \cdot \mathrm{cm}^{-1} \cdot{ }^{15}$ Much lower Li-ion conductivities at room temperature, in the order of $10^{-7}$ $\mathrm{S} \cdot \mathrm{cm}^{-1}$ or $10^{-4} \mathrm{~S} \cdot \mathrm{cm}^{-1}$, respectively, were reported by different groups. ${ }^{13-16}$ Li-ion conductivity of $10^{-6} \mathrm{~S} \cdot \mathrm{cm}^{-1}$ at room temperature was achieved in nanocrystalline $\mathrm{Li}_{2} \mathrm{~B}_{12} \mathrm{H}_{12}{ }^{15}$ which, however, is not sufficient for the utilization for solid-state electrolyte applications in batteries.

Nanoconfinement has been reported as an effective approach to tune the thermodynamic and kinetic properties of material. ${ }^{22}$ For example, nanoconfined $\mathrm{LiBH}_{4}$ using nonporous carbon or zeolite scaffolds shows faster desorption kinetics with initial desorption temperature down to below $200{ }^{\circ} \mathrm{C}$ and more importantly, improved rehydrogenation properties under moderate conditions (e.g. $260{ }^{\circ} \mathrm{C}$ to $300{ }^{\circ} \mathrm{C}$ and 5 to $10 \mathrm{Mbar}^{\mathrm{H}}$, respectively). ${ }^{23-25}$ However, it is still unclear whether $\mathrm{Li}_{2} \mathrm{~B}_{12} \mathrm{H}_{12}$ is circumvented in the hydrogen sorption cycle of nanoconfined $\mathrm{LiBH}_{4}$ or whether it is destabilized owing to a nanoconfinement effect. On the other hand, nanoconfinement enhances the cation mobility of hydrides, e.g. nano- $\mathrm{LiBH}_{4}$ shows improved ionic conductivity of $10^{-4} \mathrm{~S} \cdot \mathrm{cm}^{-1}$ at room temperature. ${ }^{26,27}$ Therefore, it is of great interest to investigate the nanoconfinement effect on $\mathrm{Li}_{2} \mathrm{~B}_{12} \mathrm{H}_{12}$. In the present study, we report the first synthesis of nanoconfined $\mathrm{Li}_{2} \mathrm{~B}_{12} \mathrm{H}_{12}$ and evaluate its thermal stability and Li-ion mobility.

Nano-porous $\mathrm{SiO}_{2}, \mathrm{SBA15}$, is used as scaffold. $\mathrm{N}_{2}$ physisorption (Fig. 1a) yields a surface area $\left(S_{B E T}\right)$ of $487.3 \mathrm{~m}^{2} / g$, a total pore volume $\left(V_{p}\right)$ of $0.765 \mathrm{~cm}^{3} / g$ and an average pore diameter of 5.9 $\mathrm{nm}$. The pore length of as-purchased SBA15 is around $1 \sim 2 \mu \mathrm{m} .{ }^{28}$ The synthesis of nanoconfined $\mathrm{Li}_{2} \mathrm{~B}_{12} \mathrm{H}_{12}$ (denoted by NC- $\mathrm{Li}_{2} \mathrm{~B}_{12} \mathrm{H}_{12}$ ) is described in Fig.1 and carried out in two steps. First, nanoconfined $\mathrm{LiBH}_{4}$ (denoted as $\mathrm{NC}-20 \mathrm{LiBH}_{4}$ ) using SBA15 as a scaffold, with a loading ratio of $20 \mathrm{wt} \%$ is prepared at $300{ }^{\circ} \mathrm{C}$ and 100 bar $\mathrm{H}_{2}$. Loading of $20 \mathrm{wt} \% \mathrm{LiBH}_{4}$ (density: $0.666 \mathrm{~g} / \mathrm{cm}^{3}$ ) corresponds to the filling of half pore volume of SBA15. Subsequently, the as-synthesized NC-2OLiBH ${ }_{4}$ is treated in a $\mathrm{H}_{2} / \mathrm{B}_{2} \mathrm{H}_{6}$ atmosphere at $150{ }^{\circ} \mathrm{C}$ to form $\mathrm{Li}_{2} \mathrm{~B}_{12} \mathrm{H}_{12}$ (density: $1.18 \mathrm{~g} / \mathrm{cm}^{3}$ ), following the reaction pathway:

$$
2 \mathrm{LiBH}_{4}+5 \mathrm{~B}_{2} \mathrm{H}_{6} \rightarrow \mathrm{Li}_{2} \mathrm{~B}_{12} \mathrm{H}_{12}+13 \mathrm{H}_{2} \quad \text { (eq.1) }
$$

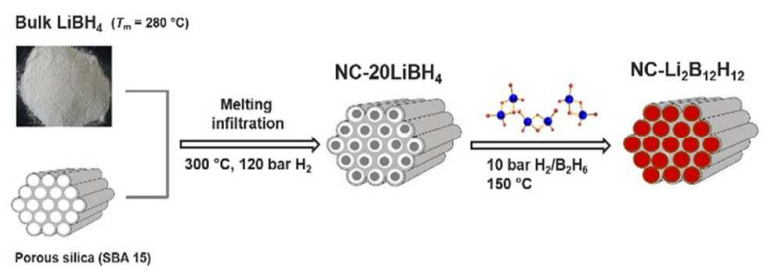

Figure 1. Illustration of synthesis of nanoconfined $\mathrm{Li}_{2} \mathrm{~B}_{12} \mathrm{H}_{12}$ (NC$\left.\mathrm{Li}_{2} \mathrm{~B}_{12} \mathrm{H}_{12}\right)$.

\footnotetext{
a. Center for Materials Crystallography, Interdisciplinary Nanoscience Center (iNANO), and Department of Chemistry, Aarhus University, Langelandsgade 140, DK-8000 Aarhus C, Denmark. E-mail: yigang.yan@inano.au.dk

b. Empa-Swiss Federal Laboratories for Materials Science and Technology, Laboratory for Functional Polymers, 8600 Dübendorf, Switzerland.

c. Empa-Swiss Federal Laboratories for Materials Science and Technology, Laboratory Materials for Energy Conversion, 8600 Dübendorf, Switzerland. Electronic Supplementary Information (ESI) available: Experimental details. See DOI: $10.1039 / x 0 \times x 00000 x$
} 

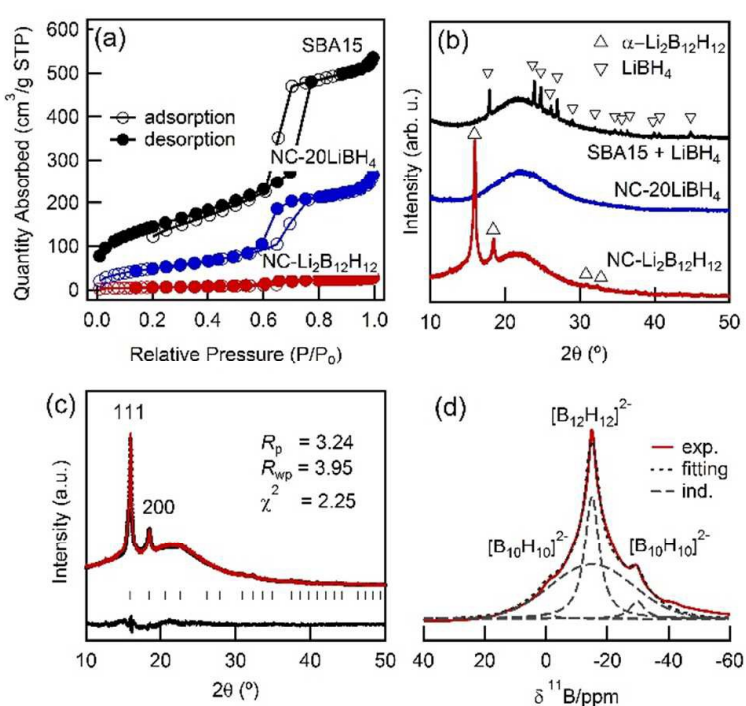

Figure 2. (a) $\mathrm{N}_{2}$ isotherms of SBA15, NC-2OLiBH $\mathrm{L}_{4}$ and $\mathrm{NC}-\mathrm{Li}_{2} \mathrm{~B}_{12} \mathrm{H}_{12}$. Open and closed circles represent adsorption and desorption isotherms, respectively. (b) XRD patterns of physical mixture of SBA15 and $\mathrm{LiBH}_{4}$ before melt infiltration, NC-2OLiBH 4 and NC$\mathrm{Li}_{2} \mathrm{~B}_{12} \mathrm{H}_{12}$. (c) Rietveld refinement of $\mathrm{NC}-\mathrm{Li}_{2} \mathrm{~B}_{12} \mathrm{H}_{12}$. The experimental data are shown as solid line, best fit as open circles and the difference plot is shown at bottom. The peak positions are referred to $\alpha-\mathrm{Li}_{2} \mathrm{~B}_{12} \mathrm{H}_{12}$ (ICSD\#249756). (d) ${ }^{11} \mathrm{~B}$ MAS NMR of NC-Li ${ }_{2} \mathrm{~B}_{12} \mathrm{H}_{12}$. The spectrum is deconvoluted into individual $\mathrm{Li}_{2} \mathrm{~B}_{12} \mathrm{H}_{12}$ and $\mathrm{Li}_{2} \mathrm{~B}_{10} \mathrm{H}_{10}$ components.
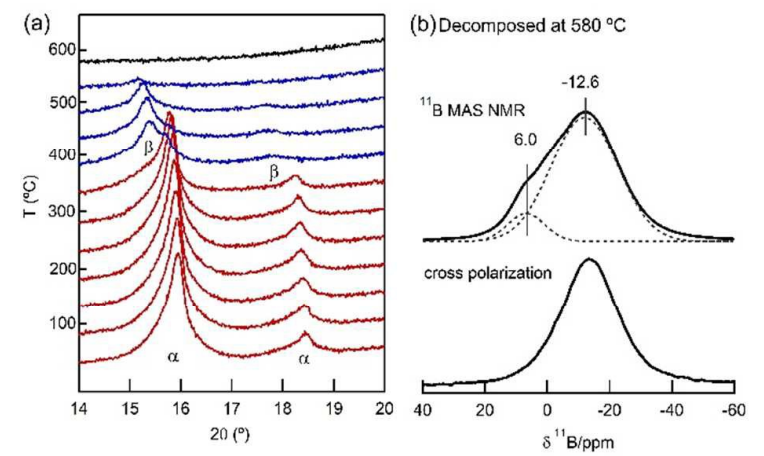

Figure 3. (a) in situ XRD patterns of $\mathrm{NC}-\mathrm{Li}_{2} \mathrm{~B}_{12} \mathrm{H}_{12}$ and (b) ${ }^{11} \mathrm{~B}$ MAS NMR and ${ }^{1} \mathrm{H}_{-}{ }^{11} \mathrm{~B}$ cross polarization MAS NMR spectra of NC$\mathrm{Li}_{2} \mathrm{~B}_{12} \mathrm{H}_{12}$ decomposed at $580{ }^{\circ} \mathrm{C}$. Dashed lines represents two individual components of the ${ }^{11} \mathrm{~B}$ MAS NMR spectrum.

The full conversion of $\mathrm{NC}-2 \mathrm{OLiBH}$ will generate a nanoconfined $\mathrm{Li}_{2} \mathrm{~B}_{12} \mathrm{H}_{12}$ with loading ratio of $47.4 \mathrm{wt} \%$, approximately corresponding to complete filling of the pore volume. Nanoconfined $\mathrm{LiBH}_{4}$ with a 34 wt\% loading (denoted as NC-34LiBH ${ }_{4}$ ), corresponding to complete filling of the pore volume of SBA15, was also prepared for evaluation of the Li-ion conductivity of nanoconfined $\mathrm{LiBH}_{4}$ as compared to the complete filling by $\mathrm{Li}_{2} \mathrm{~B}_{12} \mathrm{H}_{12}$. (a)

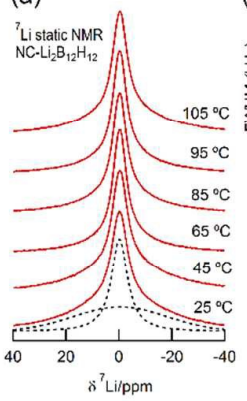

(b)

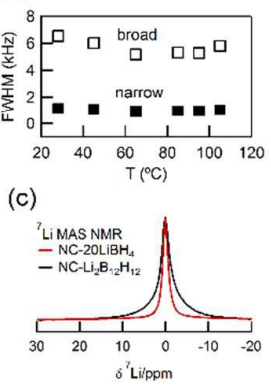

(d)

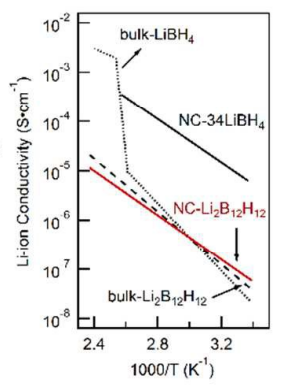

Figure 4. (a) Static ${ }^{7} \mathrm{Li} N \mathrm{NM}$ of $\mathrm{NC}-\mathrm{Li}_{2} \mathrm{~B}_{12} \mathrm{H}_{12}$ in the temperature range of 25 to $105{ }^{\circ} \mathrm{C}$. The spectrum at $25{ }^{\circ} \mathrm{C}$ is deconvoluted into a narrow Lorentzian component and a broad Gaussian component. (b) Temperature-dependent full widths at a half maximum (FWHM) of Static ${ }^{7} \mathrm{Li}$ NMR signal of NC- $\mathrm{Li}_{2} \mathrm{~B}_{12} \mathrm{H}_{12}$. (c) ${ }^{7} \mathrm{Li}$ MAS NMR $(\omega=12 \mathrm{kHz})$ of NC-LiBH ${ }_{4}$ and NC- $\mathrm{Li}_{2} \mathrm{~B}_{12} \mathrm{H}_{12}$ at $25{ }^{\circ} \mathrm{C}$. (d) Arrhenius plots of Li-ion conductivity of $\mathrm{NC}-\mathrm{Li}_{2} \mathrm{~B}_{12} \mathrm{H}_{12}$ and $\mathrm{NC}-34 \mathrm{LiBH}_{4}$, compared to bulk $\mathrm{LiBH}_{4}{ }^{29}$ and bulk $\mathrm{Li}_{2} \mathrm{~B}_{12} \mathrm{H}_{12}$. ${ }^{15}$

The change of surface area of SBA15 within the two-step process was documented by $\mathrm{N}_{2}$ sorption as shown in Fig. 2a. After loading of $20 \mathrm{wt} \% \mathrm{LiBH}_{4}, S_{\mathrm{BET}}$ and $V_{\mathrm{p}}$ are reduced to $182.3 \mathrm{~m}^{2} / \mathrm{g}$ and 0.405 $\mathrm{cm}^{3} / \mathrm{g}$, respectively. All the $\mathrm{X}$-ray reflections originating from crystalline $\mathrm{LiBH}_{4}$ precursor disappear in the X-ray diffraction (XRD) pattern of $\mathrm{NC}-2 \mathrm{OLiBH}_{4}$ (Fig. 2b), indicating the loss of long-range ordering and confirming the successful confinement in the pores of scaffold. $S_{\mathrm{BET}}$ and $V_{\mathrm{p}}$ further decrease to $27 \mathrm{~m}^{2} / \mathrm{g}$ and $0.04 \mathrm{~cm}^{3} / \mathrm{g}$ after $\mathrm{B}_{2} \mathrm{H}_{6}$ treatment, respectively, and new $\mathrm{X}$-ray reflections appear indicating the formation of $\mathrm{Li}_{2} \mathrm{~B}_{12} \mathrm{H}_{12}$ (Fig. 2b). Rietveld refinement (Fig. 2c) was performed for the as-synthesized nanoconfined $\mathrm{Li}_{2} \mathrm{~B}_{12} \mathrm{H}_{12}$, further indicating that all the new $\mathrm{X}$-ray reflections are attributed to $\alpha-\mathrm{Li}_{2} \mathrm{~B}_{12} \mathrm{H}_{12}$. However, the asymmetric feature of (111) reflection implies that coexistence of a small portion of hightemperature $\beta$ - $\mathrm{Li}_{2} \mathrm{~B}_{12} \mathrm{H}_{12}$ (space group $\mathrm{Fm}-3 \mathrm{~m}$ ) at room temperature could not ruled out. ${ }^{21} \mathrm{NC}-\mathrm{Li}_{2} \mathrm{~B}_{12} \mathrm{H}_{12}$ shows broad reflections, e.g. the dominant reflection (111) at $2 \theta=15.98$ displays a large FWHM of 0.34 degree, in agreement with its nanoconfined structure suppressing long-range order.

The formation of $\mathrm{Li}_{2} \mathrm{~B}_{12} \mathrm{H}_{12}$ is confirmed by ${ }^{11} \mathrm{~B}$ magic angle spinning nuclear magnetic resonance (MAS NMR) (Fig. 2d), where a narrow and a broad resonance at $-15.0 \mathrm{ppm}$ assigned to $\mathrm{Li}_{2} \mathrm{~B}_{12} \mathrm{H}_{12}$ are observed. Two shoulders at -0.4 and $-29.6 \mathrm{ppm}$, respectively, can be assigned to $\mathrm{Li}_{2} \mathrm{~B}_{10} \mathrm{H}_{10}$. By deconvoluting the ${ }^{11} \mathrm{~B}$ MAS NMR spectrum, it is found that the product contains $94 \mathrm{~mol} \% \mathrm{Li}_{2} \mathrm{~B}_{12} \mathrm{H}_{12}$ and $6 \mathrm{~mol} \% \mathrm{Li}_{2} \mathrm{~B}_{10} \mathrm{H}_{10}$. No residual resonance of $\mathrm{LiBH}_{4}$ is detected.

Fig. 3a shows the temperature evolution of the XRD pattern of $\mathrm{NC}-\mathrm{Li}_{2} \mathrm{~B}_{12} \mathrm{H}_{12}$ from 30 to $580{ }^{\circ} \mathrm{C}$. The transition of low-temperature $\alpha-\mathrm{Li}_{2} \mathrm{~B}_{12} \mathrm{H}_{12}$ to high-temperature $\beta-\mathrm{Li}_{2} \mathrm{~B}_{12} \mathrm{H}_{12}$, characterized by an abrupt shift in the reflections (111) and (200), is observed at $380^{\circ} \mathrm{C}$. At higher temperatures, the reflections of the $\beta$ phase decrease and fully disappear at $580{ }^{\circ} \mathrm{C}$, indicating the occurrence of decomposition. In the ${ }^{11} \mathrm{~B}$ MAS NMR spectrum of the decomposed $\mathrm{NC}-\mathrm{Li}_{2} \mathrm{~B}_{12} \mathrm{H}_{12}$ (sample heated to $580{ }^{\circ} \mathrm{C}$ ) in Fig. $3 \mathrm{~b}$, the resonance shifting to $-12.6 \mathrm{ppm}$ is assigned to $\mathrm{H}$-deficient $\mathrm{Li}_{2} \mathrm{~B}_{12} \mathrm{H}_{12-\mathrm{x}}$ and a shoulder at $6 \mathrm{ppm}$ possibly originating from elemental boron is observed. ${ }^{30}$ The formation of $\mathrm{H}$ - deficient $\mathrm{Li}_{2} \mathrm{~B}_{12} \mathrm{H}_{12-\mathrm{x}}$ is confirmed by ${ }^{1} \mathrm{H}-{ }^{11} \mathrm{~B}$ cross polarization MAS NMR (Fig. 3b).

The Li dynamics of $\mathrm{NC}-\mathrm{Li}_{2} \mathrm{~B}_{12} \mathrm{H}_{12}$ was investigated by ${ }^{7} \mathrm{Li}$ static NMR in a temperature range from 25 to $105^{\circ} \mathrm{C}$, as shown in Fig. 4 a. 
At $25^{\circ} \mathrm{C}$, the spectrum of $\mathrm{NC}-\mathrm{Li}_{2} \mathrm{~B}_{12} \mathrm{H}_{12}$ contains a relatively narrow Lorentzian component $(1.1 \mathrm{kHz})$ and a broader Gaussian component $(6.5 \mathrm{kHz})$. With increasing temperature, no significant line narrowing in the spectra and no decrease in full width at half maximum (FWHM) are observed (Fig. 4b). Fig. 4c compares the ${ }^{7} \mathrm{Li}$ MAS NMR spectra of NC- $\mathrm{Li}_{2} \mathrm{~B}_{12} \mathrm{H}_{12}$ and NC-2OLiBH${ }_{4}$ at $25^{\circ} \mathrm{C}$. The NC$\mathrm{Li}_{2} \mathrm{~B}_{12} \mathrm{H}_{12}$ shows a FWHM of $0.52 \mathrm{kHz}$, which is larger than that of $\mathrm{NC}-2 \mathrm{LiBH}_{4}(0.23 \mathrm{kHz})$. This line narrowing implies a slight decrease of $\mathrm{Li}^{+}$mobility after the $\mathrm{B}_{2} \mathrm{H}_{6}$ treatment of $\mathrm{NC}-2 \mathrm{OLiBH}_{4}$.

Fig. $4 \mathrm{~d}$ compares the Li-ion conductivity of nanoconfined $\mathrm{LiBH}_{4}$ with nanoconfined $\mathrm{Li}_{2} \mathrm{~B}_{12} \mathrm{H}_{12}$. The nanoconfined $\mathrm{LiBH}_{4}, \mathrm{NC}-34 \mathrm{LiBH}_{4}$ shows Li-ion conductivity of $8.0 \times 10^{-6} \mathrm{~S} \cdot \mathrm{cm}^{-1}$ at $25^{\circ} \mathrm{C}$. Overloading will increase the fraction of $\mathrm{LiBH}_{4}$ with high mobility. The assynthesized $\mathrm{NC}-\mathrm{Li}_{2} \mathrm{~B}_{12} \mathrm{H}_{12}$ in $\mathrm{SiO}_{2}$ scaffold exhibits a lower Li-ion conductivity around $1.0 \times 10^{-7} \mathrm{~S} \cdot \mathrm{cm}^{-1}$ at $25^{\circ} \mathrm{C}$, similar to the value obtained for bulk $\mathrm{Li}_{2} \mathrm{~B}_{12} \mathrm{H}_{12}$ which is synthesized from the wetchemistry. $^{15}$

Above all, we demonstrate the synthesis of nanoconfined $\mathrm{Li}_{2} \mathrm{~B}_{12} \mathrm{H}_{12}$ using nanoporous $\mathrm{SiO}_{2}$ as scaffold. The yield of $\mathrm{Li}_{2} \mathrm{~B}_{12} \mathrm{H}_{12}$ is up to $94 \mathrm{~mol} \%$ with 6 mol\% $\mathrm{Li}_{2} \mathrm{~B}_{10} \mathrm{H}_{10}$ formed as a byproduct determined by ${ }^{11} \mathrm{~B}$ MAS NMR measurement, where no residual of $\mathrm{LiBH}_{4}$ precursor remains. Such a high yield is much superior to that ( 26 mol\%) of the synthesis via the reaction of bulk $\mathrm{LiBH}_{4}$ and $\mathrm{B}_{2} \mathrm{H}_{6}$ at $200{ }^{\circ} \mathrm{C} .{ }^{31}$ This improvement is owing to the utilization of nanconfined $\mathrm{LiBH}_{4}$ that overcomes the limitation resulted from the formation of a passivation layer, which was observed in the reaction between bulk $\mathrm{LiBH}_{4}$ and $\mathrm{B}_{2} \mathrm{H}_{6}$. Thus high-purity and anhydrous $\mathrm{Li}_{2} \mathrm{~B}_{12} \mathrm{H}_{12}$ is provided in present study, which will used as a precursor for the synthesis of mixed-anion systems that can reach high ionic conductivity at ambient temperature. ${ }^{17-19}$

The nanocrystalline $\mathrm{Li}_{2} \mathrm{~B}_{12} \mathrm{H}_{12}$ exhibits a structural transition to the high-temperature $\beta$ phase around $380{ }^{\circ} \mathrm{C}$. The $\beta$ phase decomposes around $580{ }^{\circ} \mathrm{C}$ leading to the conversion of the material into $\mathrm{H}$-deficient $\mathrm{Li}_{2} \mathrm{~B}_{12} \mathrm{H}_{12-x}$. Similar observations are were found for bulk $\mathrm{Li}_{2} \mathrm{~B}_{12} \mathrm{H}_{12}{ }^{21}$ indicating that no obvious destabilization effect is achieved in the as-synthesized nanoconfined $\mathrm{Li}_{2} \mathrm{~B}_{12} \mathrm{H}_{12}$. The destabilization effect of nanoconfinement owes in a great extent to the interaction between scaffold and the active material. ${ }^{22}$ Such interactions have been observed in the case of other complex hydrides such as $\mathrm{LiBH}_{4}$ and $\mathrm{NaAlH}_{4}$, which is evidenced by considerable changes of ${ }^{11} \mathrm{~B}$ (or ${ }^{27} \mathrm{Al}$ ) NMR chemical shifts. ${ }^{32,33}$ In the recently reported nanoconfined $\mathrm{LiBH}_{4}$, this interaction enables the formation of an active $\mathrm{LiBH}_{4}-\mathrm{SiO}_{2}$ interface resulting in fast $\mathrm{Li}$-ion conduction at room temperature. ${ }^{26,27}$ The ${ }^{11} \mathrm{~B}$ NMR shift of assynthesized $\mathrm{Li}_{2} \mathrm{~B}_{12} \mathrm{H}_{12}$, i.e. $-15 \mathrm{ppm}$, is in line with the reported value of bulk $\mathrm{Li}_{2} \mathrm{~B}_{12} \mathrm{H}_{12}$, implying only weak interaction between $\mathrm{Li}_{2} \mathrm{~B}_{12} \mathrm{H}_{12}$ and SBA15. As a result, we do not observe an increase of $\mathrm{Li}$-ion conduction in the as-synthesized nanoconfined $\mathrm{Li}_{2} \mathrm{~B}_{12} \mathrm{H}_{12}$.

The Li-ion conductivity of $8.3 \times 10^{-6} \mathrm{~S} \cdot \mathrm{cm}^{-1}$ at $25^{\circ} \mathrm{C}$ observed for $\mathrm{NC}-34 \mathrm{LiBH}_{4}$ is two order of magnitude higher than that of bulk $\mathrm{LiBH}_{4}$ (Fig.3d), supporting the presence of highly conductive interface due to the interaction between $\mathrm{LiBH}_{4}$ and SBA15. However, this value is lower than the reported conductivity $\left(\sim 10^{-4} \mathrm{~S} \cdot \mathrm{cm}^{-1}\right.$ at $\left.40{ }^{\circ} \mathrm{C}\right)$ for nanoconfined $\mathrm{LiBH}_{4}$ with a overloading of 20 to $30 \%$, ${ }^{26}$ suggesting that overloading will improve the conductivity. In future work, we expect higher conductivity in nanoconfined $\mathrm{Li}_{2} \mathrm{~B}_{12} \mathrm{H}_{12}$ due to overloading and nanoconfinement effects in scaffold with smaller pore sizes due to larger surface/bulk ratio.

In summary, nanoconfined $\mathrm{Li}_{2} \mathrm{~B}_{12} \mathrm{H}_{12}$ using nanoporous $\mathrm{SiO}_{2}$ as scaffold with a high yield of $\mathrm{Li}_{2} \mathrm{~B}_{12} \mathrm{H}_{12}$ of 94 mol\% is synthesized via the reaction between nanoconfined $L_{2} B_{12} H_{12}$ and $B_{2} H_{6}$. The nanocrystalline $\mathrm{Li}_{2} \mathrm{~B}_{12} \mathrm{H}_{12}$ exhibits a structural transition to the high- temperature $\beta$ phase around $380{ }^{\circ} \mathrm{C}$. The $\beta$ phase decomposes around $580{ }^{\circ} \mathrm{C}$ leading to the conversion of the material into $\mathrm{H}$ deficient $\mathrm{Li}_{2} \mathrm{~B}_{12} \mathrm{H}_{12-x}$. The Li-ion conductivity of nanoconfined $\mathrm{Li}_{2} \mathrm{~B}_{12} \mathrm{H}_{12}$ is measured to be $1.0 \times 10^{-7} \mathrm{~S} \cdot \mathrm{cm}^{-1}$ at $25^{\circ} \mathrm{C}$.

We are grateful to the Danish research council (HyNanoBorN). We also like to thank the Swiss National Science Foundation for financial support within the Sinergia project 'Novel ionic conductors' under contract number CRSII2_160749/1. The NMR hardware was partially granted by the Swiss National Science Foundation (SNFS, under contract number 206021_150638/1.).

\section{Notes and references}

1. T. He, P. Pachfule, H. Wu, Q. Xu and P. Chen, Nature Reviews Materials, 2016, 1, 16059.

2. M. Paskevicius, L. H. Jepsen, P. Schouwink, R. Cerny, D. B. Ravnsbaek, Y. Filinchuk, M. Dornheim, F. Besenbacherf and T. R. Jensen, Chem Soc Rev, 2017, 46, 1565-1634.

3. B. R. S. Hansen, M. Paskevicius, H. W. Li, E. Akiba and T. R. Jensen, Coordin Chem Rev, 2016, 323, 60-70.

4. R. Mohtadi and S.-i. Orimo, Nature Reviews Materials, 2016, 2, 16091.

5. Y. Yan, R.-S. Kühnel, A. Remhof, L. Duchêne, E. C. Reyes, D. Rentsch, Z. Łodziana and C. Battaglia, Adv Energy Mater, DOI: 10.1002/aenm.201700294, 1700294-n/a.

6. S. I. Orimo, Y. Nakamori, N. Ohba, K. Miwa, M. Aoki, S. Towata and A. Zuttel, Appl Phys Lett, 2006, 89.

7. S. J. Hwang, R. C. Bowman, J. W. Reiter, J. Rijssenbeek, G. L. Soloveichik, J. C. Zhao, H. Kabbour and C. C. Ahn, J Phys Chem C, 2008, 112, 3164-3169.

8. V. Ozolins, E. H. Majzoub and C. Wolverton, J Am Chem Soc, 2009, 131, 230-237.

9. Y. G. Yan, H. W. Li, H. Maekawa, K. Miwa, S. Towata and S. Orimo, J Phys Chem C, 2011, 115, 19419-19423.

10. M. P. Pitt, M. Paskevicius, D. H. Brown, D. A. Sheppard and C. E. Buckley, J Am Chem Soc, 2013, 135, 6930-6941.

11. T. J. Udovic, M. Matsuo, A. Unemoto, N. Verdal, V. Stavila, A. V. Skripov, J. J. Rush, H. Takamura and S. Orimo, Chem Commun, 2014, 50, 3750-3752.

12. Y. Sadikin, M. Brighi, P. Schouwink and R. Černý, Adv Energy Mater, 2015, DOI: 10.1002/aenm.201501016, n/an/a.

13. L. Q. He, H. W. Li, H. Nakajima, N. Tumanov, Y. Filinchuk, S. J. Hwang, M. Sharma, H. Hagemann and E. Akiba, Chem Mater, 2015, 27, 5483-5486.

14. J. A. Teprovich, H. Colon-Mercado, A. L. Washington Ii, P. A. Ward, S. Greenway, D. M. Missimer, H. Hartman, J. Velten, J. H. Christian and R. Zidan, Journal of Materials Chemistry A, 2015, 3, 22853-22859.

15. W. S. Tang, M. Matsuo, H. Wu, V. Stavila, A. Unemoto, S.i. Orimo and T. J. Udovic, Energy Storage Materials, 2016, 4, 79-83.

16. A. Unemoto, K. Yoshida, T. Ikeshoji and S.-i. Orimo, Mater Trans, 2016, 57, 1639-1644.

17. K. Yoshida, T. Sato, A. Unemoto, M. Matsuo, T. Ikeshoji, T. J. Udovic and S.-i. Orimo, Appl Phys Lett, 2017, 110, 103901.

18. Y. Sadikin, P. Schouwink, M. Brighi, Z. Łodziana and R. Černý, Inorg Chem, 2017, 56, 5006-5016. 
19. L. Duchene, R. S. Kuhnel, D. Rentsch, A. Remhof, H. Hagemann and C. Battaglia, Chem Commun, 2017, 53, 4195-4198.

20. T. J. Udovic, M. Matsuo, W. S. Tang, H. Wu, V. Stavila, A. V. Soloninin, R. V. Skoryunov, O. A. Babanova, A. V. Skripov, J. J. Rush, A. Unemoto, H. Takamura and S. Orimo, Adv Mater, 2014, 26, 7622-7626.

21. M. Paskevicius, M. P. Pitt, D. H. Brown, D. A. Sheppard, S. Chumphongphan and C. E. Buckley, Phys Chem Chem Phys, 2013, 15, 15825-15828.

22. P. E. de Jongh and T. M. Eggenhuisen, Adv Mater, 2013, 25, 6672-6690.

23. P. Ngene, M. van Zwienen and P. E. de Jongh, Chem Commun, 2010, 46, 8201-8203.

24. J. Shao, X. Z. Xiao, X. L. Fan, X. Huang, B. Zhai, S. Q. Li, H. W. Ge, Q. D. Wang and L. X. Chen, Nano Energy, 2015, 15, 244-255.

25. P. Ngene, M. H. W. Verkuijlen, C. Barre, A. P. M. Kentgens and P. E. de Jongh, Nano Energy, 2016, 22, 169-178.

26. D. Blanchard, A. Nale, D. Sveinbjornsson, T. M.

Eggenhuisen, M. H. W. Verkuijlen, Suwarno, T. Vegge, A.
P. M. Kentgens and P. E. de Jongh, Adv Funct Mater, 2015, 25, 184-192.

27. Y. S. Choi, Y.-S. Lee, K. H. Oh and Y. W. Cho, Phys Chem Chem Phys, 2016, 18, 22540-22547.

28. http://www.acsmaterial.com/sba-15-20g-815.html).

29. M. Matsuo, Y. Nakamori, S.-i. Orimo, H. Maekawa and H. Takamura, Appl Phys Lett, 2007, 91, 224103.

30. Y. G. Yan, A. Remhof, S. J. Hwang, H. W. Li, P. Mauron, S. Orimo and A. Zuttel, Phys Chem Chem Phys, 2012, 14, 6514-6519.

31. O. Friedrichs, A. Remhof, S. J. Hwang and A. Züttel, Chem Mater, 2010, 22, 3265-3268.

32. M. H. W. Verkuijlen, J. B. Gao, P. Adelhelm, P. J. N. van Bentum, P. E. de Jongh and A. P. M. Kentgens, J Phys Chem C, 2010, 114, 4683-4692.

33. M. H. W. Verkuijlen, P. Ngene, D. W. de Kort, C. Barre, A. Nale, E. R. H. van Eck, P. J. M. van Bentum, P. E. de Jongh and A. P. M. Kentgens, J Phys Chem C, 2012, 116, 2216922178. 


\section{Page 5 of 5}

\section{Graphical abstract}
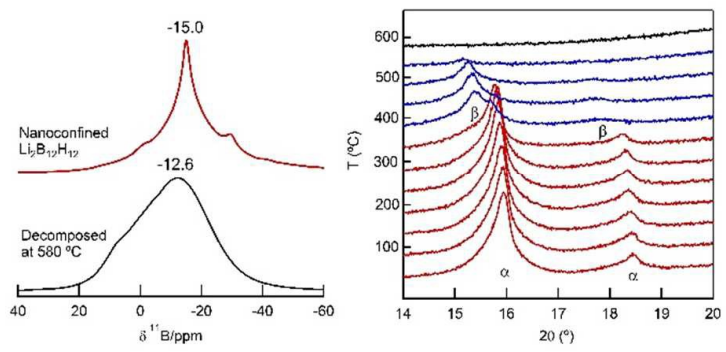

We demonstrate the first synthesis of nanoconfined $\mathrm{Li}_{2} \mathrm{~B}_{12} \mathrm{H}_{12}$ using nano-porous $\mathrm{SiO}_{2}$ scaffold and evaluate the thermal stability and $\mathrm{Li}$-ion mobility. 